\title{
PERFORMANS PRODUKSI DAN TEBAL KERABANG BURUNG PUYUH BETINA(Coturnix coturnix japonica) UMUR 6-14 MINGGU PADA LAMA PENCAHAYAAN YANG BERBEDA.
}

\author{
A. Suleman, L. Lambey*, F. Nangoy, J. Laihad. \\ Fakultas Peternakan Universitas Sam Ratulangi Manado, 95115
}

\begin{abstract}
ABSTRAK
Penelitian ini bertujuan untuk mengetahui pengaruh lama pencahayaan terhadap performans produksi burung puyuh betina umur $6-14$ minggu. Ransum yang digunakan adalah SP-22 oleh P.T Sinta Feedmill, burung puyuh yang digunakan sebanyak 80 ekor. Kandang yang digunakan adalah kandang sistem baterrey ukuran $60 \mathrm{~cm}$ x $40 \mathrm{~cm}$, dan lampu dengan daya 5 watt. Variabel yang diukur adalah konsumsi pakan, puncak produksi, berat telur, dan tebal kerabang. Rancangan yang digunakan dalam penelitian ini adalah RAL dengan 4 perlakuan dan 5 ulangan. Tiap ulangan (percobaan) menggunakan 4 ekor burung puyuh dengan perlakuan; $\mathrm{R} 0=$ 12 jam pencahayaan; $\mathrm{R} 1=16$ jam pencahayaan; $\mathrm{R} 2=20$ jam pencahayaan; $\mathrm{R} 3=24$ jam pencahayaan. Hasil analisis ragam menunjukan lama pencahayaan tidak berpengaruh terhadap rataan konsumsi pakan $(\mathrm{P}>0.05)$. Hasil analisis ragam produksi telur menunjukan lama pencahayaan tidak berpengaruh nyata terhadap produksi telur $(\mathrm{P}>0.05)$. Hasil analisis ragam lama pencahayaan tidak berpengaruh nyata terhadap berat telur $(\mathrm{P}>0.05)$. Hasil analisis ragam menunjukan lama pencahayaan tidak berpangaruh nyata terhadap tebal kerabang telur $(\mathrm{P}>0.05)$. Dapat disimpulkan bahwa penambahan cahaya selama 12 jam tidak mempengaruhi terhadap konsumsi pakan, puncak produksi, berat telur dan tebal kerabang pada burung puyuh betina umur 6 - 14 minggu.
\end{abstract}

*Korespondensi (corresponding author) Email: lucialambey@yahoo.com
Kata Kunci: Puyuh, Performans produksi, Lama pencahayaan

\section{ABSTRACT}

PERFORMANCE

PRODUCTION AND EGG SHELL THICKNESS OF QUAIL (Coturnix coturnix japonica) AT 6-14 WEEKS OLD AT DIFFERENT LIGHTING LENGTH. This study was done to determine the effect of the lighting length on the performance of quail production at 6-14 weeks old. This research was conducted at the experimental laboratory of Animal Production Department, Faculty of Animal Husbandry Sam Ratulangi University Manado, during the period from January 7, 2017 to March 3, 2017. The ration used was SP-22 commercial feed by PT. Sinta Fredmill. The total of quails used were 80 birds. Birds were maintained in a $60 \mathrm{~cm} \times 40 \mathrm{~cm}$ baterrey system, using 5 watts power light. The variables measured were feed consumption, egg production and peak production, egg weight, and thickness of the egg shell. The design used in this study was a completely randomized design with 4 treatments and 5 replications. Each replication of experiment involved 4 quails with the treatments; R0 $=12$ hours of illumination; $\mathrm{R} 1=16$ hours of illumination; $\mathrm{R} 2=20$ hours of illumination; R3 $=24$ hours of illumination. Feeding and drinking water were prepared ad libitum. The result of the analysis showed that duration of lighting did not affect the averages of feed consumption, egg production, egg weight and egg shell thickness, but peak production could be reached more than 
$80 \%$ at the thirteenth week. Therefore, it can be concluded that the addition of light for female quail production at 6-14 weeks old did not affect feed consumption, peak production, egg weight, and thickness of the egg shell

Keywords: Quail, performance production, lighting length illumination

\section{PENDAHULUAN}

Budidaya burung puyuh telah lama dilakukan oleh masyarakat.Jenis burung puyuh yang sering dipelihara dan dibudidayakan untuk dimanfaatkan telurnya adalah dari jenis Coturnix coturnix japonica. Gelap atau terhambatnya cahaya akan merangsang kelenjar pineal untuk memproduksi hormon melatonin, akibatnya produksi melatonin yang berlebih akan menyebabkan terhambatnya perkembangan seksual (Cockrem, 1985). Unggas merupakan ternak yang peka terhadap rangsangan cahaya. Cahaya memegang peranan penting dalam proses pertumbuhan, pendewasaan kelamin dan produksi telur pada ternak unggas. Pada periode starter cahaya berperan penting dalam proses pertumbuhan melalui pengaturan sekresi hormon somatotropik (Card dan Nesheim, 1972). Pencahayaan adalah parameter penting dari produksi unggas. Pencahayaan merupakan faktor eksogen yang kuat dalam mengontrol banyak proses fisiologis dan perilaku.
Pencahayaan mungkin merupakan faktor yang paling kritis dari semua faktor lingkungan bagi unggas.

Salah satu aspek tatalaksana pemeliharaan burung puyuh untuk produksi telur adalah pencahayaan yang dapat berpengaruh pada performans produksi, yaitu konsumsi pakan, puncak produksi, berat telur, dan tebal kerabang namun lama pencahayaan yang tepat masih perlu dilakukan penelitian, sehingga permasalahan yang dapat dirumuskan pada penelitian ini adalah apakah lama pencahayaan yang diberikan dapat mempengaruhi performans pruduksi telur burung puyuh betina.Penelitian ini bertujuan untuk mengetahui pengaruh lama pencahayaan terhadap performans produksi burung puyuh betina umur 6 minggu -14 minggu sebagai standar awal bertelur sampai puncak produksi telur.Performa produksi burung puyuh meliputi konsumsi pakan,puncak produksi, berat telur, dan tebal kerabang.

\section{MATERI DAN METODE PENELITIAN}

\section{Materi Penelitian}

Ternak yang digunakan dalam penelitian ini adalah burung puyuh jenis Coturnix cournix japonicaumur $6-14$ minggu. Jumlah burung puyuh yang 
dipelihara sebanyak 80 ekor berjenis kelamin betina.Pakan yang digunakan dalam penelitian ini adalah pakan jadi periode layer. Kandang yang digunakan adalah kandang system koloni. Setiap kandang dibagi dalam lima buah sekat dan setiap sekat terdapat 4 unit, masing masing unit berisi 5 ekor burung puyuh. Suhu kandang selama penelitian yaitu ratarata $26^{\circ} \mathrm{C}$. Pakan diproduksi oleh PT Sinta Prima Feedmill. Peralatan yang digunakan dalam penelitian ini adalah lampu pijar dengan daya 5 watt, sebanyak 20 buah. Peralatan lainnya adalah micrometer sekrup, timbangan, tempat pakan, tempat minum dan penampungan telur.

\section{Rancangan Penelitian}

Penelitian ini menggunakan Rancangan Acak Lengkap.Sebagai perlakuan ialah lama pencahayaan. Terdiri dari 4 taraf perlakuan: R0, R1, R2, dan R3. Pengulangan dilakukan sebanyak 5 kali. Penambahan cahaya dilakukan mulai Pukul 18.00 dengan perlakuan sebagai berikut: R0 :Tanpa perlakuan penambahan cahaya R1 :Penambahan cahaya selama 4 jam dari pukul $18.00-22.00$

R2 :Penambahan cahaya selama 8 jam dari pukul $18.00-02.00$

R3 :Penambahan cahaya selama 12 jam dari pukul $18.00-06.00$

Model matematika yang digunakan adalah $\boldsymbol{Y} \boldsymbol{i} \boldsymbol{j}=\boldsymbol{\mu}+\boldsymbol{\alpha} \boldsymbol{i}+\boldsymbol{\varepsilon} \boldsymbol{i} \boldsymbol{j}$
$\boldsymbol{Y} \boldsymbol{i} \boldsymbol{j}:$ Nilai pengamatan pada pemberian cahaya ke - i dan ulangan ke $-\mathrm{j}$

$\boldsymbol{\mu}$ : Rataan umum

$\boldsymbol{\alpha i}$ : Pengaruh perlakuan pemberian cahaya $\mathrm{ke}-\mathrm{i}$ dan ulangan ke $\mathrm{j}$

$\boldsymbol{\varepsilon} \boldsymbol{i} \boldsymbol{j}$ : Pengaruh galat percobaan pemberian cahaya $\mathrm{ke}-\mathrm{i}$ pada ulangan $\mathrm{ke}-\mathrm{j}$

\section{Analisis data}

Data yang diperoleh pada penelitian ini dianalisis ragam (Anova) untuk mengetahui pengaruh perlakuan terhadap peubah yang diamati. Apabila terdapat hasil yang berbeda maka dilanjutkan dengan uji beda nyata jujur (BNJ).

\section{Variabel Yang di Amati}

Variabel yang diamati selama penelitian meliputi :

1) Konsumsi pakan dihitung dengan cara menimbang pakan yang diberikan dan menimbang sisa pakan setiap harinya selama periode pemeliharaan. Konsumsi pakan dihitung dari pakan yang diberikan dikurangi dengan sisa pakan (Sumbawati, 1992).

2) Berat telur dihitung dengan cara menimbang telur selama penelitian/ekor (Sihombing et al., 2006)

3) Puncak produksi dihitung berdasarkan berapa banyak jumlah telur yang dihasilkan puyuh selama periode penelitian (Tetty, 2002). 
4) Tebal kerabang dihitung dengan menggunakan caliper sebagai pengukur selama periode penelitian (Sudrajat et al., 2014).

\section{Persiapan kandang}

Persiapan kandang dan peralatan dilakukan satu minggu sebelum pelaksanaan penelitian. Sebelum penelitian kandang dan peralatan disuci hamakan menggunakan air kapur kemudian dikeringkan. Lampu dan tempat pakan dan minum diletakan di setiap kandang sebanyak satu buah pada tiap sekat.

\section{Pemeliharaan}

Pemberian pakan dilakukan pada pagi hari pukul 07.00 dan siang hari pukul 13.00 wita. Sedangkan untuk air minum tersedia secara ad libitum. Pencatatan dilakukan pada pemberian pakan harian dan sisa pakan untuk mengetahui konsumsi pakan. Pengambilan telur dilakukan sehari sekali yaitu pada malam hari pukul 19.00 Wita.

Pencatatan dilakukan pada jumlah telur tiap kandang dilakukan setiap hari selama penelitian untuk mengetahui jumlah telur. Pengukuran tebal kerabang telur dilakukan setiap minggu untuk mengetahui pengaruh peneltian terhadap tebal kerabang.

Pemberian vitamin vitastres dilakukan setelah pindah kandang selama tiga hari berturut-turut, untuk menghilangkan stress setelah pindah kandang. Pemberian puyuh Medi Egg yang berfungsi untuk merangsang produksi telur dilakukan seminggu sekali.

\section{HASIL DAN PEMBAHASAN}

\section{Pengaruh Perlakuan Terhadap Konsumsi Pakan}

Rataan konsumsi pakan bervariasi antara 20,11 g - 20,26 g/ekor/hari (Tabel 3). Rataan konsumsi pakan ini masih berada pada kisaran penelitian yang dilakukan Kusumoastuti (1992) pada puyuh petelur umur 13-19 minggu yaitu 18,16-23,59 g/ekor/hari, tetapi masih lebih rendah dari hasil penelitian yang dilakukan oleh Makund et al. (2006) yaitu 30,02 g/ekor/hari.

Berdasarkan hasil analisis sidik ragam menunjukkan bahwa lama pencahayaan yang berbeda pada burung puyuh umur 6 - 14 minggu memberikan pengaruh yang tidak berbeda nyata terhadap konsumsi pakan $(\mathrm{P}>0.05)$. North dan Bell, (1990) menyatakan bahwa pada ternak unggas, ada faktor pembatas konsumsi pakan yaitu kapasitas tembolok dan kebutuhan energi. Burung puyuh yang mendapatkan cahaya lebih lama akan mempunyai kesempatan untuk mengkonsumsi pakan lebih banyak dari pada yang lain, tetapi adanya faktor 
Tabel 1. Rataan varibel yang diukur

\begin{tabular}{lcccc}
\hline \multirow{2}{*}{ Variabel } & \multicolumn{4}{c}{ Perlakuan } \\
\cline { 2 - 5 } & $\mathrm{R} 0$ & $\mathrm{R} 1$ & $\mathrm{R} 2$ & $\mathrm{R} 3$ \\
\hline Konsumsi (g) & 20,11 & 20,19 & 20,21 & 20,26 \\
Puncak Produksi (\%) & 86,14 & 87,85 & 87,66 & 83,09 \\
Berat Telur $(\mathrm{g})$ & 9,83 & 9,87 & 9,85 & 9,88 \\
Tebal Kerabang $(\mathrm{mm})$ & 0,1705 & 0,1631 & 0,1615 & 0,1516 \\
\hline
\end{tabular}

pembatas tersebut menyebabkan burung puyuh akan berhenti makan ketika kebutuhan energinya telah terpenuhi.

\section{Pengaruh Perlakuan Terhadap Puncak Produksi}

Hasil Penelitian menunjukan puncak produksi puyuh dicapai pada umur 13 minggu dengan presentase berkisar antara $77,85 \%-90,71 \%$, seperti penelitian Tetty (2002) yang menyatakan bahwa puyuh mencapai puncak produksi lebih dari $80 \%$ pada minggu ke-13, tetapi masih lebih tinggi dibandingkan dengan penelitian Makund et al. (2006) yaitu 57,83\% $60,72 \%$. Menurut Wuryadi (2011) puncak produksi puyuh petelur terjadi pada umur 3 - 5 bulan (12 - 20 minggu) dengan rata-rata produksi telur dalam satu populasi berkisar 78 - $85 \%$. Tatalaksana pemeliharaan selama periode produksi sangat menentukan kemampuan puyuh dalam memproduksi telur. Dalam penelitian ini produksi telur pada awal bertelur sampai umur 12 minggu masih mengalami fluktuasi dan mulai stabil pada umur 13-14 minggu.

\section{Pengaruh Perlakuan Terhadap Berat Telur}

Standar berat telur burung puyuh berkisar antara 9,30 g - 9,78 g/butir (Sihombing et al., 2006). Pada burung puyuh yang berumur 8 - 9 minggu yang diberi pakan dengan kandungan protein $22 \%$ berat telurnya 9,2 g. Pada umur $20-$ 21 dan 31 - 32 minggu, pemberian pakan dengan kandungan protein $22 \%$ berat telurnya 10,1 g dan 11,0 g (Eishu et al., 2005). North dan Bell (1990) menyatakan bahwa berat telur biasanya seragam, hanya pada telur double yolk dan telur abnormal lainnya yang tidak seragam. Pola alami produksi telur yaitu telur yang dihasilkan pada awal bertelur berukuran kecil dan semakin besar sampai berat telur yang stabil. Rataan berat telur selama penelitian umur 6-14 minggu adalah 9,83 - 9,88 g/butir. Rataan berat telur tersebut lebih tinggi dari hasil penelitian yang dilakukan (Eishu et al., 2005) pada burung puyuh 
yang berumur 8-9 minggu dengan pemberian pakan yang mengandung protein $22 \%$ yaitu $9,2 \mathrm{~g}$.

Berdasarkan hasil analisis ragam, pengaruh perlakuan terhadap berat telur adalah tidak berbeda nyata $(\mathrm{P}>0.05)$. Hal ini menunjukan bahwa penambahan cahaya tidak mempengaruhi berat telur yang di hasilkan.karena berat telur merupakan sifat yang diwariskan oleh induk atau genetik (Ensminger, 1992).

\section{Pengaruh Penelitian Terhadap Tebal Kerabang Telur}

Tebal kerabang telur didapat dengan mengukur tebal kerabang dengan membran telur (mm). Pengukuran tebal kerabang telur dilakukan pada bagian ujung tumpul, tengah (ekuator), dan ujung lancip telur kemudian dibuat rata-rata. Kerabang telur adalah suatu struktur mineral yang tersusun terutama dari $\mathrm{CaCO}$. Kerabang telur terdiri dari dua bagian yaitu kerabang tipis (membran) dan kerabang telur keras.Pada penelitian ini jenis dan umur puyuh, jenis pakan, konsumsi pakan, serta penggunaan cahaya penerangan yang digunakan adalah sama sehingga rataan tebal kerabang telur puyuh yang diperoleh berkisar antara $0,1615 \mathrm{~mm}$ - 0,1705 mm sehingga perlakuan tidak berbeda nyata. Pengukuran tebal kerabang telur dilakukan pada bagian ujung tumpul, tengah (ekuator), dan ujung lancip telur menggunakan alat mikrometer, kemudian dibuat rata-rata.

Hasil analisis ragam menunjukkan bahwa pencahayaan R0, R1, R2 dan R3, tidak berbeda nyata terhadap tebal kerabang telur $(\mathrm{P}>0,05)$. Tebal kerabang telur mempunyai hubungan yang berbanding terbalik dengan suhu lingkungan, suhu yang tinggi akan mempengaruhi kualitas putih telur dan mengurangi kekuatan dan ketebalan cangkang telur (Achmanu et al., 2011).

\section{KESIMPULAN}

Dari penelitian ini dapat disimpulkan bahwa penambahan pencahayaan selama 12 jam tidak mempengaruhi konsumsi, puncak produksi, berat telur dan tebal kerabang

\section{DAFTAR PUSTAKA}

Achmanu, Muharlien dan Salaby. 2011. Pengaruh lantai kandang (rapat dan renggang) dan imbangan jantanbetina terhadap konsumsi pakan, bobot telur, konversi pakan dan tebal kerabang pada burung puyuh. J. Ternak Tropika. 12(2):1-14.

Card, L.E. dan M.C. Nesheim. 1972. Poultry Production. 11 th Ed. Lea dan Febiger.

Cockrem, JF and BK Follett. 1985. Circadian rhythm of melatonin in the pineal gland of the Japanese 
quail (Coturnix coturnix japonica). J. of Endocrinology, 317-324.

Eishu R. I., K. Sato, T. Oikawa, T. Kunieda, and H. Uchida. 2005. Effects of dietary protein levels on production andcaracteristics ofjapanese quail egg. The J. of Poultry Science, 42: 130-139.

Ensminger, M.A. 1992. Poultry Science (Animal Agriculture Series).3rd Edition.Interstate Publishers, Inc. Danville.

Kusumoastuti. E.S. 1992. Pengaruh zeolit dalam ransum puyuh (Coturnix coturnixjaponica) terhadap produksi dan kualitas telur pada periode produksi umur 13-19 minggu. Skripsi. Institut Pertanian Bogor. Bogor.

Mukund, K. M., A. B. Mandal, A. V. Elangovan, dan S. Kaur. 2006. Response of laying japanese quail to dietary calciumlevels at two levels energy. The J. of Poultry Science, $43: 351-356$.

North, M. O. dan D.D. Bell. 1990. Commercial Chicken Production Manual. Van Nostrand Reinhold. J. 42:935-941.

Sihombing, G., Avivah, dan S. Prastowo. 2006. Pengaruh penambahan zeolit dalam ransum terhadap kualitas telur burung puyuh. Agrotechnology Research Jurnal. 23: 455-481.

Sudrajat, D., D. Kardaya, E. Dihansih, S.F.S. Puteri. 2014. Performa produksi telur burung puyuh yang diberi ransum kromium organik. JITV 19: 257-262.

Sumbawati. 1992. Penggunaan beberapa tingkat zeolit dengan tingkat protein dalam ransum burung puyuh terhadap produksi telur, indeks putih telur dan indeks kuning telur. Sripsi. Fakultas peternakan. Institut Pertanian Bogor. Bogor.

Tetty, 2002. Puyuh Si Mungil Penuh Potensi. Agro Media Pustaka. Jakarata.

Wuryadi, S. 2011. Buku Pintar Beternak dan Bisnis Puyuh. Agromedia Pustaka. Jakarta. Hal. 16-18 